\title{
THE RECEPTION OF MATTHEW 27:19B (PILATE'S WIFE'S DREAM) IN THE EARLY CHURCH
}

\author{
RONALD H. VAN DER BERGH \\ UNIVERSITY OF PRETORIA
}

\begin{abstract}
The mysterious dream of Pilate's wife and its recounting to her husband (Matthew 27:19b) occupies a significant place in discussions on Pilate's guilt. The present article aims to investigate the reception of this text by the early church. Special attention is paid to the early commentators' views on the possible link between the dream of Pilate's wife and Pilate's guilt, as this is an ambiguity in the Matthean text. Another uncertainty in the Matthean text concerns the story's chronology. The early commentators' views on this matter are also examined. Lastly, the varied ways of applying this text in new contexts are investigated.
\end{abstract}

Keywords: Pilate's wife; Claudia Procula; dreams; narrative time; Pilate; Pilate's guilt; Christology

\section{INTRODUCTION}

The episode of Pilate's wife ${ }^{1}$ sending a message about her dream (Matthew 27:19b) occupies a special place in the Matthean passion narrative. Wedged between two offers of release by Pilate of either Barabbas or Jesus and two sentences concerning the chief priests and elders (thus forming an ABCBA pattern), Matthew 27:19b sends a clear message about Jesus' righteousness (and per implication, his innocence). The use of $\kappa \alpha \tau$ ' óvap (literally, 'according to a dream') confirms this view. In the New Testament, the expression is found only in Matthew, and apart from its occurrence in Matthew 27:19, only in the infancy narrative (Matt. 1:20; 2:12, 13, 19, 22). In these instances, the term appears to be a terminus technicus to indicate a message of divine origin. ${ }^{2}$ The same can be said of the dream in Matthew 27:19, albeit with caution. ${ }^{3}$ In the infancy narrative, 
$\kappa \alpha \tau$ ' óv $\alpha \rho$ always occurs together with the terms $\chi \rho \eta \mu \alpha \tau i \zeta \omega$ (in the passive form in the New Testament, always 'to receive a divine message') and paiv ('to appear'). These terms are not present in Matthew 27:19, and the way in which the dream is received also appears to be different: in the infancy narrative, the dreams are always received positively (even if Joseph is told not to be afraid), while Pilate's wife suffers ( in Matthew 27:19. ${ }^{4}$ Yet, there is sufficient evidence that Matthew views her dream as a message from God. ${ }^{5}$ Matthew 27:19 is more than just a narrative aside or a clever ploy by the narrator to allow enough time for the chief priests and elders to stir up the crowd.

The importance of Matthew 27:19b did not escape the notice of early commentators on this text, even though its evaluation varied. The present article seeks to investigate the text's reception in the early church (for the purpose of this article, to the end of the fifth century) with specific attention to three aspects, arising from the investigation itself: the relation of this text to the extent of Pilate's guilt, the specific use of time with relation to other events in the passion narrative, and the general interpretation of the function and meaning of the passage.

The first aspect under investigation is of some import, as the passage is a key text in the riddle of Matthew's views on Pilate's guilt - or that of 'the Jews.' Pilate's character and guilt has elicited a host of scholarly and more popular essays, books, and articles. ${ }^{6}$ Especially with a view to the infamous and sometimes purported to be highly antiSemitic Matthew 27:25 ('His blood be upon us and upon our children!'), the question of Matthew's assessment of Pilate's guilt becomes highly relevant. Modern day scholars and commentators diverge in their evaluation of the issue, and a clear answer does not seem to be on the near horizon. ${ }^{7}$ Relevant to this question is whether or not a causal link can be established between Pilate's declaration of Jesus' innocence, his act of hand washing and his wife's message. In other words, is the episode of Pilate's wife indeed 'determinative for Pilate's behavior,' as some modern commentators suppose? ${ }^{8}$ Did the early church perceive a causal link here?'

The second aspect to be investigated concerns the chronology of the events in the storyline of Matthew. Here, the classic distinction between fabula (story) and sjužet (discourse) comes into play. ${ }^{10}$ If the reader assumes that the narrated storyline (story) follows the sequence of events as told in the narration (discourse), the perception arises that the scene with Pilate's wife occurs after the accusations by the chief priests and elders (Matt. 27:11-14). However, this is not necessarily the case: no strict reference to time is present in the Matthean text. At any rate, this is not always the view espoused by early commentators, as will be seen below. Aside from their view of the sequence of events, the early commentators' application of time with regard to this passage will also be highlighted (see in particular the discussion of Chrysostom below).

The final aspect under investigation, the different ways in which the text is applied, may be divided into several categories. After discussing each reference to Matthew $27: 19 \mathrm{~b}$ under the heading of its author, the findings of the investigation will be systematised and summarised in the conclusion of this article. In the process, some of the exegetical concerns of the early church will be unearthed. 
Our inquiry will start with Origen, one of the earliest writers commenting on Matthew 27:19b, and then loosely follow the chronological order of early commentators up to Ambrose.

\section{THE RECEPTION OF MATTHEW 27:19B IN THE EARLY CHURCH}

\subsection{Origen}

Origen refers to the episode twice. The first reference is in his Scholia in Matthaeum ${ }^{11}$ :

While being judged by Pilate, [Jesus] sent a divine message ( $\dot{\chi} \chi \rho \mu \alpha \dot{\tau} \iota \zeta \varepsilon)$ to his wife, so that through the silence he might be astounded by (his) manliness ( $\dot{\alpha} v \delta \rho \varepsilon i \alpha v)$, but through the divine message $(\chi \rho \eta \mu \alpha \tau i \sigma \mu \tilde{\omega})$ he might know that he is not judging a man, but God ( $\theta \varepsilon \delta$ v). Therefore, he didn't see (the vision) so that he won't keep silent about it, or because he didn't believe, or because he was unworthy, but that, on hearing what his wife endured, he might feel sympathy ( $\sigma \nu \mu \pi \alpha \theta \eta \dot{\sigma \eta)}$ ). Because not only did she see the dream ( $\tau$ ò $\dot{v} v v ́ \pi v ı v)$, but she also suffered much $\left(\pi \circ \lambda \lambda \dot{\alpha} \varepsilon^{\prime} \pi \alpha \theta \varepsilon\right)$, and in the night ( $\left.\dot{\varepsilon} v \vee v \kappa \tau i ́\right)$ she grew very afraid. Moreover, the vision was a

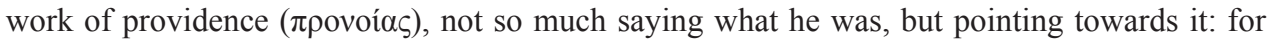
Jesus showed it not so that he shouldn't suffer, but that the woman may be saved. And blessed

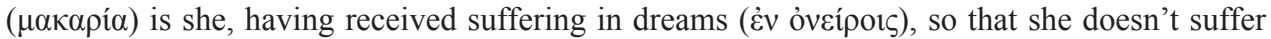
even more. If she is a symbol, it is of the church which was then under the governance of Pilate, but which is now no longer subject to him, because of faith in Christ. ${ }^{12}$

According to Origen, the dream contrasts with Jesus' silence, showing both Jesus' manliness (or: 'courageousness,' but the wordplay between $\alpha v \delta \rho \varepsilon i ́ \alpha$ and $\theta \varepsilon o ́ \varsigma$ should not be overlooked) and his divinity. Origen initially describes these two aspects as happening simultaneously (through the use of the present tense), probably to sharpen

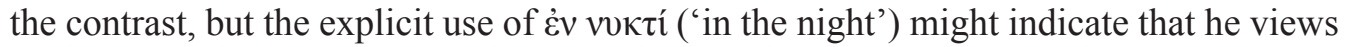
the events as following each other in sequence. Of the four reasons Origen supplies why Pilate did not receive the dream himself, it is the fourth that receives the most attention. He may so be induced to take part in the suffering of his wife, which leads to salvation. In fact, she is blessed ( $\left.\mu \alpha \kappa \alpha \rho^{\prime} \alpha\right)$ to receive this suffering, as it will prevent even more suffering later. She becomes the symbol of the church which is not under governance anymore, but rather set free through faith in Christ.

Origen's second reference to Matthew 27:19 is in Contra Celsum 2.34. ${ }^{13}$ The context of this reference is a discussion of Jesus' divinity, which Celsus denies. The latter bases his argument (mockingly) on the tragic ending of Euripides' Bacchae. ${ }^{14}$ According to

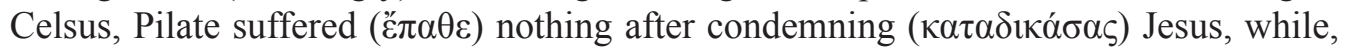
after condemning a god, Pentheus became mad and was torn apart ( $\sigma \pi \alpha \rho \alpha \chi \theta \varepsilon i ́(\varsigma)$. Origen counters in a twofold manner. First, he states that it was not so much Pilate who

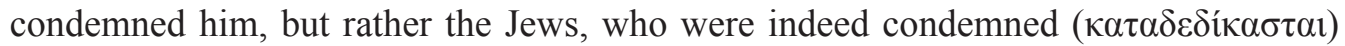
by God and torn apart $(\sigma \pi \alpha \rho \alpha \chi \theta \dot{\varepsilon} v)$ and scattered over all the earth in a way exceeding Pentheus' dismemberment ( $\sigma \pi \alpha \rho \alpha \gamma \mu$ óv). Second, Origen accuses Celsus of omitting the 
detail about the dream of Pilate's wife and quotes her words, ending with: 'For today in a dream I have suffered much ( $\pi \partial \lambda \lambda \dot{\alpha}$ है $\pi \alpha \theta 0 v)$ on account of him.' Origen probably changed the order of these words to emphasize her great amount of suffering (compare

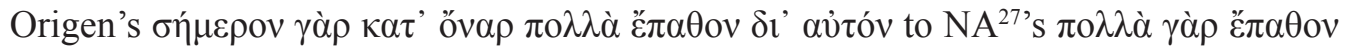

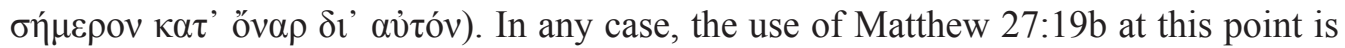
again to affirm Jesus' divinity, which he makes evident by way of the dream.

\subsection{Cyril of Jerusalem}

Cyril of Jerusalem makes reference to Matthew 27:19 in his Catecheses ad illuminandos (13.16), ${ }^{15}$ which concerns itself with Jesus' trial scene, death and burial. The quotation below is from the scene before Pilate:

While being judged, [Jesus] was silent, so that Pilate became distressed (vं $\varepsilon \rho \pi \alpha ́ \sigma \chi \varepsilon ı v)$ and said: "Do you not hear what things they accuse you of?" (He said this) not because he knew him who was being judged ( had been sent (to him).

For Cyril, the dream (غ่vvi $\pi v i o v)$ has an effect upon Pilate's actions, and becomes the reason behind Pilate's question ('Do you not hear what things they accuse you of?'). Cyril does not tell us whether Pilate's fear of the dream has any further consequences for his actions, and consequently, does not explicitly link the dream with Pilate's guilt. His explanation does not follow the logical order of events as set out in the narration of Matthew. For his reasoning to make sense, the scene with Pilate's wife (Matt. 27:19) should occur before or at least contemporaneous with the accusation scene (Matt. 27:11-14), as it is at this point that Pilate asks this specific question.

\subsection{Hilary of Poitiers}

While Pilate was sitting on the judgement seat, his wife sent him a message, saying: "Let there be nothing between you and this righteous man (Nihil sit tibi et iusto illi)." In her is the image (species) of the pagan gentiles, that unbelieving people with whom she cohabited and at that time already (iam) reliably (fidelis) called to faith (fidem) in Christ. Since she herself suffered much (multum ... passa) on account of Christ, she invited him (illum $)^{16}$ with whom she cohabited into the same glory of the future hope. Then Pilate both washed his hands and to the Jewish nation (populo Iudaico) declared (testatus est) himself innocent of the blood of the Lord; since, while the Jews (Iudaeis) daily take upon themselves the charge of the Lord's poured out blood, the gentile people go to the confession of faith (confessionem fidei) washed clean (ablutus).

Not unlike Origen, ${ }^{17}$ Hilary of Poitiers, in his Commentarius in evangelium Matthaei (33.1), ${ }^{18}$ views Pilate's wife as a type of the Gentile believers to come. She, already 'faithful' (iam fidelis), calls the unbelieving people - and her husband - to faith in Christ (ad Christi fidem advocat). Her suffering for Christ (pro Christo) becomes the catalyst for calling her husband 'into the same glory of the future hope' (in eamdem gloriam 
futurae spei). Pilate reacts positively (denique Pilatus ....) to his wife's message: he washes his hands and declares his innocence of Jesus' blood to the Jewish people. Hilary concludes with an application of his exposition to his own day: while the Jews and their sons daily take upon themselves the charge of the Lord's blood, the Gentiles go to confession of faith washed clean. ${ }^{19}$

\subsection{Athanasius of Alexandria}

In Epistula ad Maximum $1,{ }^{20}$ Athanasius congratulates Maximus on his arguments against the Arians. He explains his own initial silence by pointing out the foolishness of replying to matters which are so readily apparent. Basing his argument on the trials before Pilate and Caiaphas, Athanasius argues that Christ exemplified this way of conduct:

\footnotetext{
Since, to Pilate, after he washed (his hands) and comprehended the dishonest persecution of the Jews of the time, the Lord did not any longer give an answer, but rather gave a divine message

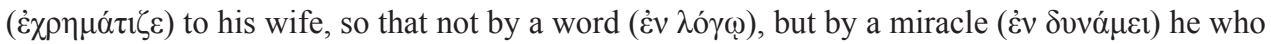

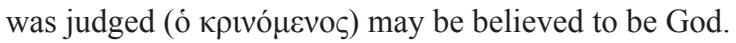

Similarly, Caiaphas was not given an answer, but Christ 'brought everyone into

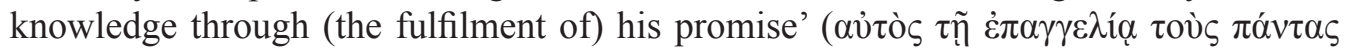
$\varepsilon i \varsigma \gamma v \tilde{\omega} \sigma \mathrm{v} \nu \mu \varepsilon \tau \eta \gamma \gamma \gamma \varepsilon v)$. Athanasius' argument builds on a different order of events than the narration in Matthew, at least with respect to Jesus' silence (which is mentioned in Matt. 27:14). Even if Athanasius understood the dream to have occurred before Pilate washed his hands, the full effect of the message only becomes apparent after the handwashing incident. Here, as in other early commentators, the reason for the dream is to prove Jesus' divinity.

The same theme of Jesus' divinity can be found in Athanasius' Homilia de passione et cruce domine,${ }^{21}$ although the work may be spurious. Similar to Origen, Ps.-Athanasius

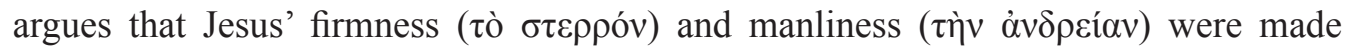
manifest by his silence, while by a divine message $(\chi \rho \eta \mu \alpha \tau 1 \sigma \mu \tilde{\varphi})$ Pilate 'may know that

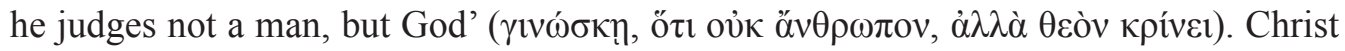
is once more the active subject of the verb $\chi \rho \eta \mu \alpha \tau i \zeta \omega$. Ps.-Athanasius goes on to say

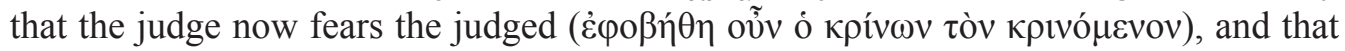

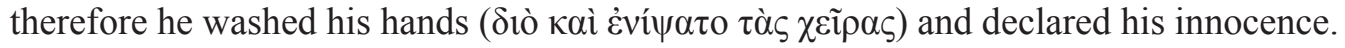
Whether Pilate is absolved of guilt is not to be discerned, but here is a definite link between the dream and Pilate's actions.

Ps.-Athanasius mentions the incident in Matthew 27:19b twice more. In his summary of Matthew, Synopsis scripturae sacrae ${ }^{22}$ he notes that 'the wife of Pilate counselled

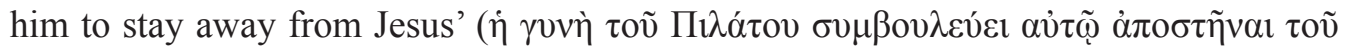
'Inбoṽ). Thus he views the essence of the passage as a warning. The final reference to Matthew 27:19b by Ps.-Athanasius, question 20 of his Quaestiones in evangelia, ${ }^{23}$ is used almost verbatim by Chrysostom (In Matthaeum 86.1) and is discussed below. 


\subsection{Asterius}

A certain Asterius, previously identified with Asterius the Sophist, ${ }^{24}$ in a homily on Psalm 18, Commentarii in Psalmos (homiliae 31) (29.16), ${ }^{25}$ applies Matthew 27:19b in a context of the theme of proclamation of the good news. After a series of 'positive' characters announcing news to other positive characters (e.g., Andrew to Peter), each time

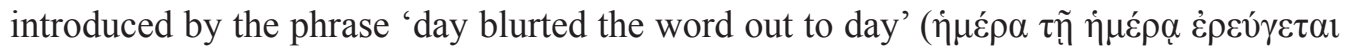
$\dot{\rho} \tilde{\eta} \mu \alpha)$, Asterius turns to 'negative' characters. His repeatedly used introductory formula

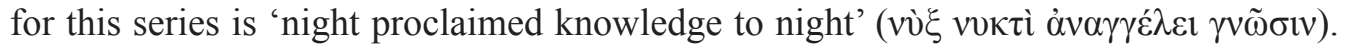
After a reference to the story of the exodus (introduced by 'an Egyptian said to an Egyptian'), Asterius states: 'And night proclaimed knowledge to night, and (his) wife

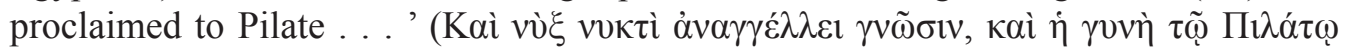
$\dot{\alpha} v \alpha \gamma \gamma \varepsilon \dot{\varepsilon} \lambda \operatorname{cov\sigma \alpha }$ ), with Matthew 27:19b as the content of the proclamation. The next

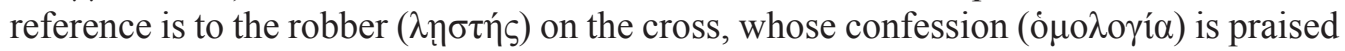

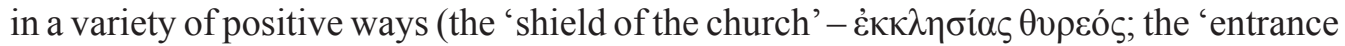
of paradise' $-\pi \alpha \rho \alpha \delta \varepsilon i ́ \sigma o v$ óvor $\gamma \mu \alpha$ etc.). Although the robber might have started out as negative, he is now viewed in a positive light. The same is true for the next group of characters: Nebuchadnezzar and 'the Babylonians.' By analogy, the wife of Pilate (the first in the series) should also be seen as the 'negative' character now turned positive and proclaiming the good news to another 'negative' character.

\subsection{Ephraem the Syrian}

Ephraem, in his Sermo in transfigurationem domini et dei salvatoris nostri Iesu Christi ${ }^{26}$ applies Matthew 27:19 to the theme of humanity / divinity. The whole verse fits snugly into Ephraem's series of alternating questions ('if not flesh, who did ...' and

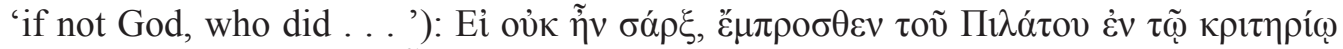

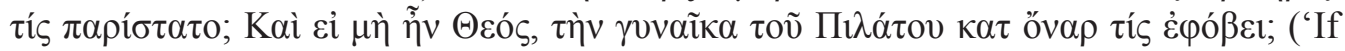
he wasn't flesh, who stood before Pilate in the tribunal? And if he wasn't God, who frightened the wife of Pilate with a dream?') Once again, Matthew 27:19b functions as proof of Jesus' divinity.

\subsection{Chrysostom}

In Expositiones in Psalmos 47, ${ }^{27}$ an exposition of LXX Psalm 46, Chrysostom discusses Christ's victory as reason for joy. The reader is warned not to think that Christ is defeated, even when bound or in death:

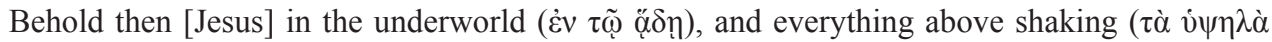
$\ddot{\alpha} \pi \alpha \nu \tau \alpha \sigma \varepsilon i ́(v \tau \alpha)$. For at that time the sun turned away its rays, rocks were split, the curtain was torn, the earth trembled, Judas hanged himself, Pilate and his wife were afraid ( $\dot{\varepsilon} \delta \varepsilon 1 \mu \alpha \tau o$ ṽo), the

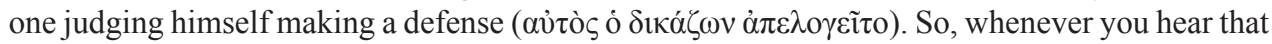
he was bound and scourged, do not be troubled ( $\mu$ ๆे $\sigma v \gamma \chi v \theta \tilde{n} \varsigma)$; but behold him displaying (his)

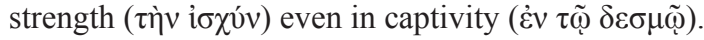


All of this is possible, Chrysostom explains, because of Christ's exalted nature (vँ $\psi 1 \sigma \tau \varsigma \varsigma$

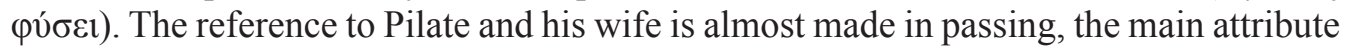
being their fear. Noteworthy here is the confluence of time: these things all seem to

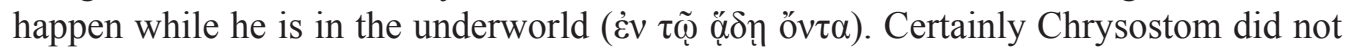
envision the dream of Pilate's wife after the crucifixion, and the reference to Pilate speaking in defence is based on the passion narrative in the Gospel of John. Chrysostom more likely shows some poetic licence in his disregard for time. ${ }^{28}$ In piling up all these incidents, he heightens the rhetorical effect of his argument about Christ's nature. The same device can be seen in the following excerpt from his treatise on Matthew 26:39, Pater, si possible est, transeat ${ }^{29}$ :

And what does the following mean: "Lying down, he slept like a lion"? Just as a lion is terrifying (

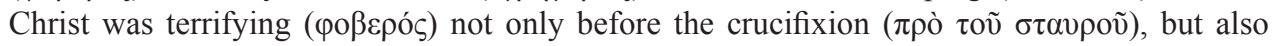

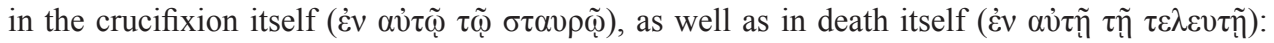
even then $(\tau o ́ \tau \varepsilon)$ he worked great marvels: turning away the sun, ripping open rocks, making

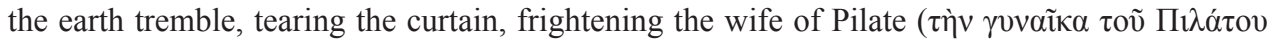
$\delta \varepsilon \delta \imath \tau \tau$ ó $\mu \varepsilon v o \varsigma)$, convicting Judas. For at that time he said: "I have sinned betraying innocent blood." And the wife of Pilate made it evident ( $\dot{\varepsilon} \delta \dot{\eta} \lambda$ ov): "Let there be nothing between you and

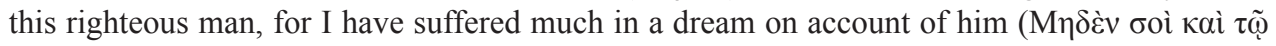

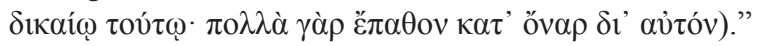

Before this passage, Chrysostom explained that both Christ and the prophets knew about his inevitable crucifixion. Since he counts Jacob amongst the prophets, Chrysostom quotes Genesis 49:9, which is part of Jacob's blessing on Judah. This is done to illustrate Christ's nature (ovoí $\alpha$ ) as the Son, who knows the Father. According to Chrysostom, Genesis 49:9 is a prediction of Christ's crucifixion - the sleeping lion is a metaphor for Christ's death. Just as a lion is scary even when it sleeps, Christ is powerful even in death. He performs a number of miraculous deeds, either from the other side of the grave, or on the cross. Among this list, again, are Pilate's wife and Judas.$^{30}$ Chrysostom again puts strict chronological considerations aside in favour of argumentative power, even if he is using 'the cross itself' ( $\alpha$ vìò $\tau$ ò $\sigma \tau \alpha \nu \rho o ́ \varsigma)$ as a reference to the whole passion narrative. This use of 'the cross itself' can be seen in the text quoted below, a list found in Chrysostom's homily on Matthew 25:31ff., In Matthaeum 79, ${ }^{31}$ which is similar to the previous two quotations. The purpose of the list is, however, different: Chrysostom exhorts his audience not only to do good works to those who deserve it, but also to those who do not deserve it. He upholds Christ as an example of meekness amidst assault, even while he was powerful enough to stop it. 'Everything that [Christ]

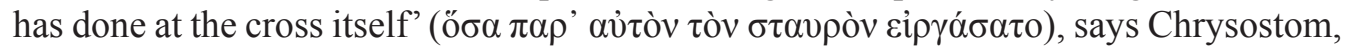
was written down so that his audience might imitate goodness ( $\alpha \gamma \alpha \theta$ ó $\eta \uparrow \tau)$ and might strive for love of others ( $\varphi i \lambda \alpha v \theta \rho \omega \pi i \alpha)$. 


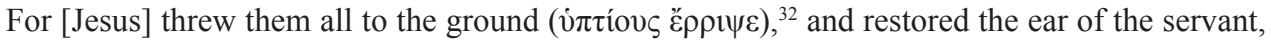
and conversed with gentleness; and while above displayed great marvels: turning the rays (of the sun) away, tearing open rocks, raising the dead, frightening the wife of the one judging (him)

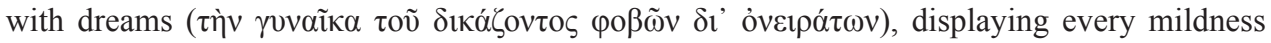
$\left(\pi \tilde{\alpha} \sigma \alpha \nu \pi \rho \alpha \sigma_{\tau} \eta \tau \alpha\right)$ in the trail itself . . . .

Chrysostom concludes his examples from the passion narrative by saying that 'in

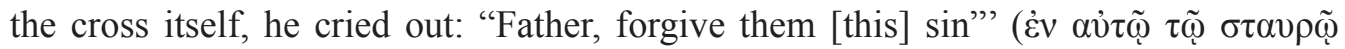

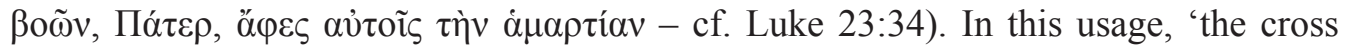
itself' signifies a specific moment. The emphasis again falls on the contrast between the seeming passivity of Christ in judgement while working miraculous deeds. The point Chrysostom wishes to make differs from the previous two passages, as here the argument is paraenetical: to teach meekness and right conduct. Pilate's wife's fear (by way of dreams - note the plural, perhaps also added for rhetorical effect) is simply listed as one of these works of power.

The next two instances where Chrysostom mentions Matthew 27:19b treat the dream of Pilate's wife as a warning to Pilate - upon which he should have acted. The first of these is found in Chrysostom's homily on Matthew 27:11-12 ${ }^{33}$ :

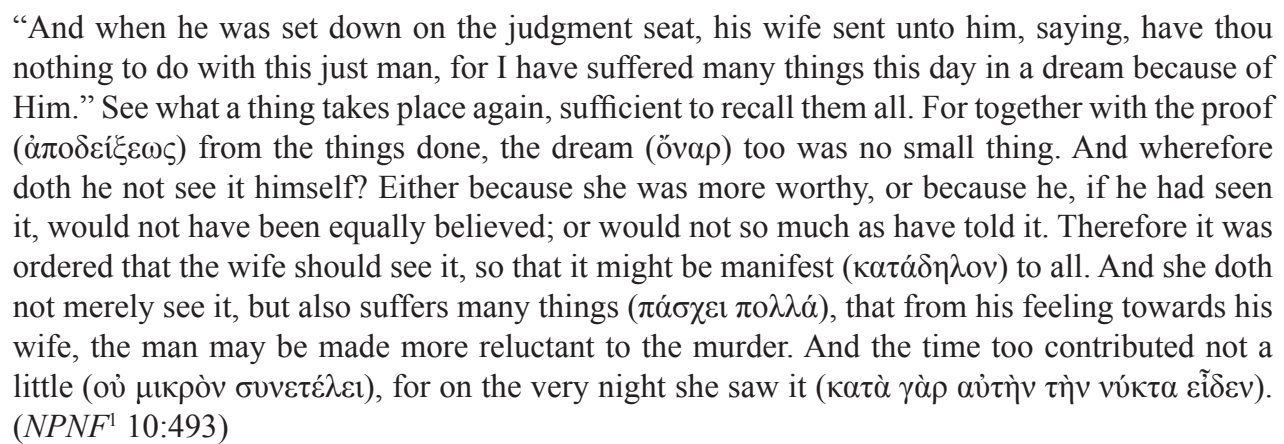

The context, also in the sermon, is the trial before Pilate and the accusations made by the Jewish leaders. In this homily Chrysostom followed the timeline provided by Matthew's narration. He does not make explicit whether Pilate acted upon his wife's dream, but places Pilate's offer of release of either Jesus or Barabbas (Matt. 27:15-18, 20-23) before the passage quoted above, instead of having these two episodes occur concurrently. The dream serves only as the final warning $;{ }^{34}$ Pilate is already convinced of Jesus' innocence. Using almost exactly the same words as Athanasius (Quaestiones in evangelia 20), Chrysostom speculates that she was given the dream instead of Pilate because of her greater worth, but the preferred explanation seems to be that the dream was thus made public. The audience is never explicitly told why Chrysostom considers this aspect so important.

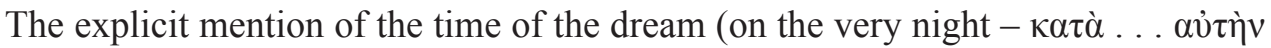

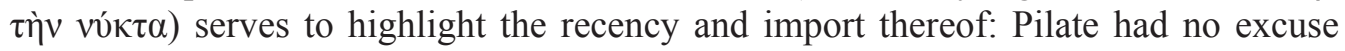


in this regard. In much the same way, his wife's suffering should have alarmed Pilate to the urgency of the dream's message. Chrysostom points out both these aspects to emphasize the dream's function as a warning to Pilate. The same goes for a passage in which Chrysostom refers to Matt 27:19: In Joannem $85 .{ }^{35}$ In this homily on John 19:1618, Chrysostom describes how Pilate should have asked whether Christ was pursuing earthly power, but failed to do so. Knowing Pilate's failure to ask beforehand, Christ pre-emptively offered the answer: 'My kingdom is not of this world' ( $\dot{\eta} \dot{\varepsilon} \mu \grave{\eta} \beta \alpha \sigma \lambda \lambda \varepsilon i ́ \alpha$

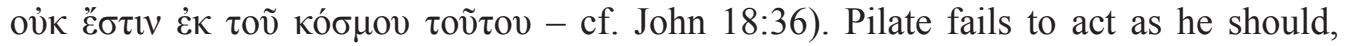
'[a]nd yet his wife's dream should have been sufficient to terrify him' (this translation

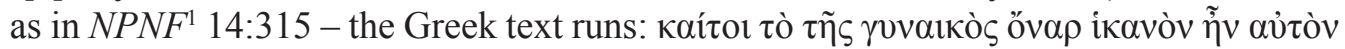
$\kappa \alpha \tau \alpha \pi \lambda \tilde{\eta} \xi \alpha \iota)$.

Another passage in which Matthew 27:19b is used as proof of Christ's divinity in an indirect manner is in sancta lumina sive in baptismum et in tentationem 6.5.3, ${ }^{36}$ most probably a spurious work. ${ }^{37}$ The context is again that of the crucifixion. Christ is made to speak: 'I am God' ( $\theta \varepsilon$ ó $\zeta$ ciu). Ps.-Chrysostom then repeatedly challenges the audience to ask ( $\dot{\varepsilon} \rho \omega ́ \tau \eta \sigma o v)$ various entities concerning this fact: the sun hiding away and producing night; the rocks splitting apart; the curtain tearing; the hanging betrayer; the judge declaring Christ's innocence; and the wife of Pilate revealing: 'Don't have

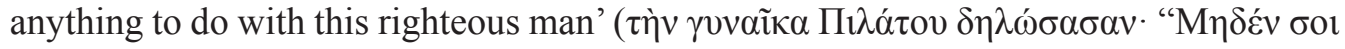

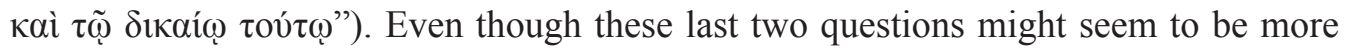
concerned with Christ's innocence and his righteousness, they are here presented as rhetorical questions confirming Christ's divinity.

Yet another mention of Pilate's wife is made by (a possibly spurious) work by Ps.-Chrysostom on the day of preparation, In sancta et magna parasceve. ${ }^{38}$ The passage describes the dream as a warning, but of special interest here is the emphasis on gender. It is fitting ("丷 $\pi \rho \varepsilon \pi \varepsilon)$ that 'the Jews' are defeated $(\dot{\eta} \tau \tau \tilde{\alpha} \sigma \theta \alpha l)$ by a woman. Ps.-Chrysostom supplies other examples of victorious (the word used is viká $\omega$ ) women: Rahab; the woman who had a discharge of blood; and the Canaanite woman. In addition,

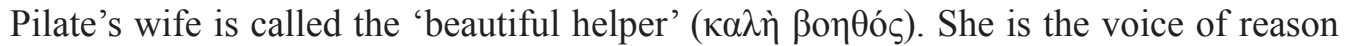

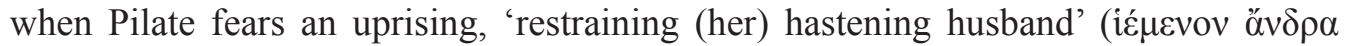
$\kappa \alpha \tau \varepsilon ́ \chi 0 v \sigma \alpha$ ) with the words of Matthew 27:19b. Ps.-Chrysostom gives two further clues on his view of Matthew 27:19b by adding that she says ( $\lambda \varepsilon \dot{\gamma}$ ov $\sigma \alpha$ - but maybe this should rather be translated 'as if she is saying'): 'If you are able, save him; but if not,

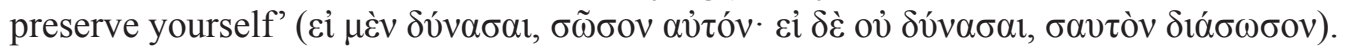
Pilate is at least offered the option of distancing himself from the whole affair - advice which he does act upon. Ps.-Chrysostom next states that Pilate's wife's stopped short ( $\mu$ ovovovxí) of applying (LXX) Psalm 25:9 to Pilate: 'Let not your soul be destroyed

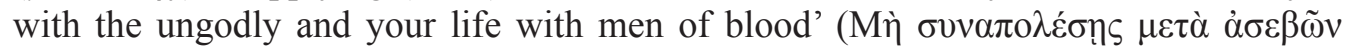

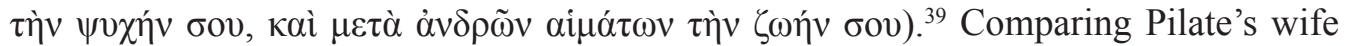
to Joseph ${ }^{40}$, Ps.-Chrysostom notes that she also saw the truth through dreams ( $\delta i \alpha \grave{\tau} \tau \tilde{\omega} v$

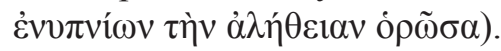




\subsection{Ambrose of Milan}

Ambrose, in his Expositio evangelii secundum Lucam $(10.100-101)^{41}$ is more concerned with Pilate and Pilate's guilt than Pilate's wife:

Indeed, Pilate washed his hands, but did not wash away what happened; for a judge ought to give place to neither prejudice (invidiae) nor fear (timori), so that he does not consent to the blood of an innocent man. His wife warned him (monebat uxor); grace shone forth in the night; divinity became evident (divinitas eminebat): but he did not abstain from such a sacrilegious judgement (a sacrilega sententia temperauit). Similarly, I think, the type (typum) of all judges who condemn those who they deem innocent (innoxios) is made known in him in advance.

Ambrose ameliorates Pilate's character in the next sentence, as he is more capable of being tolerable than the Jews (Iudaeos). Pilate is not absolved from guilt; he acts even though his wife warns him. His wife's vision is described without direct reference to it being given to her - rather, 'grace' and 'divinity' become the active subjects of the sentence. This creates a more direct link with what his wife saw and the warning being given to Pilate. It is as if these things were revealed to Pilate himself. In so doing, Ambrose emphasizes the aspect of warning evident in the text.

\section{CONCLUSION}

The present article sought to investigate three aspects of the early church's reception of Matthew 27:19b: the question regarding the link between Pilate's wife's dream and his guilt; the question of time; and the general application of Matthew 27:19b in early commentators' works.

Early commentators had quite different views on how to evaluate the effects of Pilate's wife's dream. Ambrose, for instance, finds Pilate guilty in not paying heed to his wife's warning. At the other end of the spectrum, Hilary believes Pilate to be absolved exactly because he regarded her warning. For Hilary, one should add, this was at the expense of the Jews. In a similar vein to Hilary, Origen emphasized the salvation brought about by the dream, rather than explicitly linking Pilate's guilt with his wife's warning. Cyril also does not explicitly link the dream with Pilate's guilt, but he does note that it influenced Pilate's actions. Finally, Chrysostom was of the opinion that Pilate should have acted on his wife's urgent warning - but did not. Per implication, Pilate's brushing aside of the dream assigns him guilt.

Some interesting details emerged in the early commentators' use of time. Without apparent reason, both Athanasius and Cyril present the events of Matthew 27 in a different order than presented in the Matthean text. In the case of Origen and especially Chrysostom, this difference in time could not be accidental. Both Origen and Chrysostom present events as concurrent to heighten rhetorical effect. This begs the question: did Athanasius and Cyril also rearrange the order as some sort of rhetorical device? A complete analysis of their works with regard to time is needed to comprehensively answer this question - something which, of course, falls outside the scope of this article. 
The contexts in which Matthew 27:19b is applied are of a varied character. Its most frequent use by early commentators is as proof of Jesus' divinity (Origen, Athanasius, Ps.-Athanasius, Ephraem and Chrysostom). This does not seem a prominent concern in the text of Matthew, but was certainly a hot topic in the early church. Naturally, Matthew 27:19b was also seen as a warning to Pilate (especially Ps.-Athanasius and Chrysostom). Chrysostom applies the text in a discussion on daily Christian living: with the exhortation to be meek even when being assaulted. He also touches upon the public proclamation of Christ's divinity. Along more or less the same lines, Asterius highlights Matthew 27:19b as an act of proclamation. What is declared here, however, is not Christ's divinity, but simply the 'good news. ${ }^{42}$ Part and parcel of this good news is a change of character: at least with regard to the messenger. This messenger, that is, Pilate's wife, becomes a symbol of the church set free in the writings of Origen. Likewise, Hilary views her as a symbol of the Gentile believers, calling others into the Christian fold.

\section{NOTES}

1 Pilate's wife remains unnamed in the gospel text. Later tradition assigns to her the name Claudia Procula, on the origin of which see R. Kany, "Die Frau des Pilatus und ihr Name: Ein Kapitel aus der Geschichte neutestamentlicher Wissenschaft," ZNW 86 (1995): 104-110.

2 For a discussion of the dreams in Matthew in light of ancient novels, see D. S. Dobson, "Dreams, the Ancient Novels, and the Gospel of Matthew: An Intertextual Study," PRSt 29 (2002): 39-52.

3 Cf. D. P. Senior, The Passion Narrative according to Matthew: A Redactional Study (BETL 39; Leuven: Leuven University Press, 1982), 247.

4 But see Dobson, "Dreams," 51.

5 Cf. Senior, The Passion Narrative, 248; D. P. Senior, The Passion of Jesus in the Gospel of Matthew (The Passion Series 1; Wilmington: Michael Glazier, 1985), 114; H. Bond, Pontius Pilate in History and Interpretation (SNTSMS 100; Cambridge: Cambridge University Press, 1998), 133.

6 Some notable works include: J. A. Fitzmyer, "Anti-Semitism and the Cry of 'All the People': (Mt 27:25)," Theological Studies 26 (1965): 667-71; I. Broer, "Der Prozeß gegen Jesus nach Mattäus," in Der Prozeß gegen Jesus: Historische Rückfrage und Theologische Deutung (QD 112; ed. K. Kertelge; Freiburg: Herder, 1989); K.-S. Krieger, "Pontius Pilatus - ein Judenfeind? Zur Problematik einer Pilatusbibliographie," BN 78 (1995): 63-83; Bond, Pontius Pilate; Maier (2004); C. Callon, "Pilate the Villain: An Alternative Reading of Matthew's Portrayal of Pilate," BTB 36, no. 2 (2006): 62-71; R. Groves, “'His Blood Be upon Us': Matthew 27:15-26," RevExp 103 (2006): 223-30; L. H. Cohick, "Jesus as King of the Jews," in Who Do My Opponents Say I Am? An Investigation of the Accusations against Jesus (ed. S. McKnight and J. B. Modica; London: T\&T Clark, 2008); J. Nolland, "Matthew and Anti-Semitism," in Built upon the Rock: Studies in the Gospel of Matthew (ed. D. M. Gurtner and J. Nolland; Grand Rapids: Eerdmans, 2008); C. Sider Hamilton, “'His Blood Be upon Us': Innocent Blood and the Death of Jesus in Matthew," CBQ 70 (2008): 82-100. 
7 Compare, for instance, the article of Callon ("Pilate the Villain", 62), who opines that "Matthew crafts a vehemently negative portrayal of Pilate' with Evans' view (C. A. Evans, "Excavating Caiaphas, Pilate, and Simon of Cyrene: Assessing the Literary and Archaeological Evidence," in Jesus and Archaeology (ed. J. H. Charlesworth; Grand Rapids: Eerdmans, 2006), 323-40, here 331) of 'the Gospels' portraits of a passive, almost benevolent Pilate' or Nolland ("Matthew and Anti-Semitism," 164) who thinks Matthew's Pilate "clearly hopes that the crowd will choose Jesus.' It should be noted that Nolland is not overly positive of Pilate: scholarly opinion seems to vacillate only with regard to the degree of Pilate's guilt.

8 Here U. Luz, Matthew 21-28 (Hermeneia; Minneapolis: Fortress, 2005), 492; cf. J. van Bruggen, Matteüs: Het Evangelie voor Israël (Commentaar op het Nieuwe Testament: Derde Serie; Kampen: J. H. Kok; 1990), 456; Dobson, "Dreams," 51. A contrary stance is taken by, e.g., Callon, "Pilate the Villain", 68.

9 The present article deals only with the views of commentators on Matthew 27:19b, but at least one other source which may elucidate the early church's view on a possible causal link could be noted here: in Codex Sinaiticus, a manuscript of the fourth century, Jesus is not only described

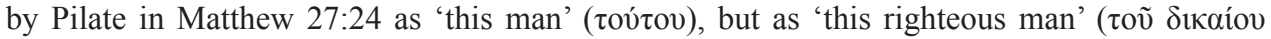

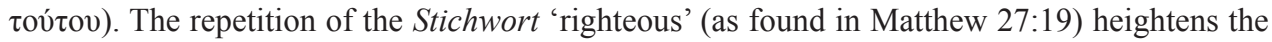
possibility of a causal link between Matt. 27:19b and Matt. 27:24. For a discussion of the textcritical issues and a positive view on the inclusion of this longer reading, see R. D. Wettlaufer, “A Second Glance at Matthew 27:24," NTS 53 (2007): 344-58.

10 Chatman's study (S. Chatman, Story and Discourse: Narrative Structure in Fiction and Film (Ithaca: Cornell University Press, 1978), see especially pages 19-22) remains an excellent starting point for understanding these concepts and their application to narrative. For a specific application of story and discourse to biblical narrative, see R. H. van der Bergh, "The Distinction between Story and Discourse in the Analysis of Biblical Narrative," JNSL 34 (2008): 83-98.

11 Origen, Scholia in Matthaeum (PG 17:308).

12 Unless stated otherwise, translations are the author's own.

13 Origen, "Contra Celsum," SC 132, 64-476.

14 Euripides, "Bacchae," in Euripidis fabulae (vol. 3; ed. J. Diggle; Oxford: Clarendon, 1994), 291-351. See especially the messenger's speech in lines 1044-1167 of the Bacchae.

15 Cyril of Jerusalem, "Catecheses ad illuminandos," in Cyrilli Hierosolymorum archiepiscopi opera quae supersunt omnia (vol. 2; ed. W. C. Reischl and J. Rupp; Munich: Lentner, 1860), $2-342$.

16 The illum could here refer to either Pilate or the people (populus) mentioned in the previous sentence. The ambiguous reference serves as a hinge to heighten the effect of the comparison.

17 Cf. E. Fascher, Das Weib des Pilatus (Matthäus 27,19). Die Auferweckung der Heiligen (Matthäus 27,51-53). Zwei Studien zur Geschichte der Schriftauslegung (Hallische Monographien 20; Halle (Saale): Max Niemeyer Verlag, 1951), 13, who takes the link to be very explicit.

18 Hilary of Poitiers, "Commentarius in evangelium matthaei," SC 258, 10-261.

19 A second reference of Hilary to Matthew 27:19 in his Tractatus super psalmos 1.10 (Hilary of Poitiers, "Tractatus super psalmos," in S. Hilarii Episcopi Pictaviensis tractatus super psalmos (CSEL 22; ed. A. Zingerle; Wien: Akademie der Wissenschaften, 1891), 3-354) mentions only Pilate in the judgement seat. Hilary comments on his Latin text of Psalm 1's 'seat of pestilence' (cathedra pestilentia). Pilate's seat is contrasted with that of Moses, occupied by the Pharisees. 
In the latter's case, the seat (i.e. the law which must be kept) was not so much the issue as its hypocritical occupants. Pilate, on the other hand, wanted to avoid the infection (contagium) of the seat he found himself in. For Hilary, this infection occurs when people 'are led astray by the canvassing for worldly honours; and desire to administer the law the courts, though they are bound by those of the Church' (NPNF 2 9:238. The Latin reads: saecularium . . honorum ambitio corrumpit: et volunt ecclesia legibus subditi fori legibus iudicare.)

20 Athanasius of Alexandria, Epistula ad Maximum 1 (PG 26:1085).

21 Athanasius of Alexandria, Homilia de passione et cruce domine (PG 28:209).

22 Athanasius of Alexandria, Synopsis scripturae sacrae (PG 28:389).

23 Athanasius of Alexandria, Quaestiones in evangelia (PG 28:704).

24 W. Kunzig (W. Kunzig, In Search of Asterius: Studies on the Authorship of the Homilies on the Psalms [Forschungen zur Kirchen- und Dogmengeschichte 47; Göttingen: Vandenhoeck \& Ruprecht; 1990]) has convincingly argued that, although these homilies form a unit, they were not written by Asterius the Sophist, but still the author carried the name Asterius. See Kunzig, In Search of Asterius, 227-232 for other possible identifications of the author.

25 Asterius, "Commentarii in Psalmos (homiliae 31)," in Asterii sophistae commentariorum in Psalmos quae supersunt (Symbolae Osloenses (fasc. Suppl. 16); ed. M. Richard; Oslo: Brogger, 1956), 3-245.

26 Ephraem the Syrian, "Sermo in transfigurationem domini et dei salvatoris nostri Iesu Christi,"

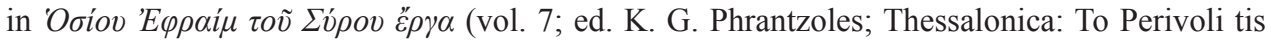
Panagias, 1998), 13-30.

27 Chrysostom, Expositiones in Psalmos 47 (PG 55:210).

28 Judas, too, is included in the list, even though the relevant episode is related already in Matthew, 27:3-10. It is likely that Matthew 27:3-10 is indeed a proleptic reference inserted by Matthew to heighten the suspense, so Chrysostom may in fact not differ too much from Matthew's implied chronology here.

29 Chrysostom, Pater, si possible est, transeat 1 (PG 51:32).

30 Fascher (Das Weib, 6) points out that the well-known Old Saxon epic poem, the Heliand, also takes Judas' death to be synchronous with the trial before Pilate. See Fascher, Das Weib, 11 for more examples of close parallels between the use of the Judas episode and that of Pilate's wife.

31 Chrysostom, In Matthaeum 79.3 (PG 58:721).

32 The reference here is to John 18:6: "When Jesus said, "I am he," they drew back and fell to

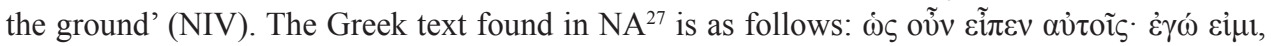

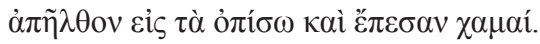

33 Chrysostom, In Matthaeum 86.1 (PG 58:764).

34 Cf. Fascher, Das Weib, 17.

35 Chrysostom, In Joannem 85.1 (PG 59:459).

36 Chrysostom, "In sancta lumina sive in baptismum et in tentationem," in Die PseudoChrysostomische Predigt In Baptismum et Tentationem (BHG 1936m; CPG 4735) (AHAW Philosophisch-historische Klasse 3; ed. K.-H. Uthemann; Heidelberg: Universitätsverlag C. Winter, 1994), 122-37. 
37 Cf. K.-H. Uthemann, Die Pseudo-Chrysostomische Predigt In Baptismum et Tentationem (BHG 1936m; CPG 4735) (AHAW Philosophisch-historische Klasse 3; Heidelberg: Universitätsverlag C. Winter, 1994), 9-11.

38 Chrysostom, In sancta et magna paraseve (PG 50:814).

39 The psalm's first person personal pronoun has been changed to a second personal pronoun in order to apply the text to Pilate.

40 Chrysostom is not clear whether this is Jesus' father or the Joseph of Genesis 37:5-11, although the use of the term غ่vvi $\pi v i o v$ instead of öva $\rho$ rather points to the latter.

41 Ambrose of Milan, "Expositio evangelii secundum Lucam," in Ambrosii Mediolanensis Opera: Pars IV (CCSL 14; ed. M. Adriaen; Turnhout: Brepols, 1957), 1-400.

42 Asterius' shunning of the topic of divinity here may be due to Arian views - but see Kunzig, In Search of Asterius, passim.

\section{BIBLIOGRAPHY}

Aland, B., K. Aland, J. Karavidopoulos, C. M. Martini, and B. M. Metzger, eds. Novum Testamentum Graece. 27th ed., 9th revised print. Stuttgart: Deutsche Bibelgesellschaft, 2006.

Ambrose. "Expositio evangelii secundum Lucam." Pages 1-400 in Ambrosii Mediolanensis Opera: Pars IV. Corpus Christianorum: Series Latina 14. Edited by M. Adriaen. Turnhout: Brepols, 1957.

Asterius. "Commentarii in Psalmos (homiliae 31)." Pages 3-245 in Asterii sophistae commentariorum in Psalmos quae supersunt. Symbolae Osloenses (fasc. suppl. 16). Edited by M. Richard. Oslo: Brogger, 1956.

Bond, H. K. Pontius Pilate in History and Interpretation. Society for New Testament Studies Monograph Series 100. Cambridge: Cambridge University Press, 1998.

Broer, I. "Der Prozeß gegen Jesus nach Mattäus." Pages 84-110 in Der Prozeß gegen Jesus: Historische Rückfrage und Theologische Deutung. Questiones Disputatae 112. Edited by K. Kertelge. Freiburg: Herder, 1989.

Callon, C. "Pilate the Villain: An Alternative Reading of Matthew's Portrayal of Pilate." Biblical Theology Bulletin 36, no. 2 (2006): 62-71.

Chatman, S. Story and Discourse: Narrative Structure in Fiction and Film. Ithaca: Cornell University Press, 1978.

Chrysostom. "In sancta lumina sive In baptismum et in tentationem." Pages 122-37 in Die PseudoChrysostomische Predigt In Baptismum et Tentationem (BHG 1936m; CPG 4735). Abhandlungen der Heidelberger Akademie der Wissenschaften. Philosophisch-historische Klasse 3. Edited by K.-H. Uthemann. Heidelberg: Universitätsverlag C. Winter, 1994.

Cohick, L. H. "Jesus as King of the Jews." Pages 111-32 in Who Do My Opponents Say I Am? An Investigation of the Accusations against Jesus. Edited by S. McKnight and J. B. Modica. London: T\&T Clark, 2008.

Cyril of Jerusalem. "Catecheses ad illuminandos." Pages 2-342 in Cyrilli Hierosolymorum archiepiscopi opera quae supersunt omnia. Vol. 2. Edited by W. C. Reischl and J. Rupp. Munich: Lentner, 1860. 
Dobson, D. S. "Dreams, the Ancient Novels, and the Gospel of Matthew: An Intertextual Study." Perspectives in Religious Studies 29 (2002): 39-52.

Ephraem the Syrian. "Sermo in transfigurationem domini et dei salvatoris nostri Iesu Christi." Pages

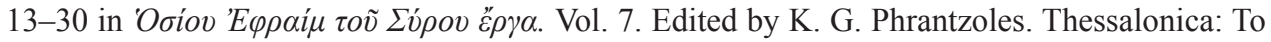
Perivoli tis Panagias, 1998.

Euripides. "Bacchae." Pages 291-351 in Euripidis fabulae. Vol. 3. Edited by J. Diggle. Oxford: Clarendon, 1994.

Evans, C. A. "Excavating Caiaphas, Pilate, and Simon of Cyrene: Assessing the Literary and Archaeological Evidence." Pages 323-40 in Jesus and Archaeology. Edited by J. H. Charlesworth. Grand Rapids: Eerdmans, 2006.

Fascher, E. Das Weib des Pilatus (Matthäus 27,19). Die Auferweckung der Heiligen (Matthäus 27,5153). Zwei Studien zur Geschichte der Schriftauslegung. Hallische Monographien 20. Halle (Saale): Max Niemeyer Verlag, 1951.

Fitzmyer, J. A. “Anti-Semitism and the Cry of 'All the People': (Mt 27:25).” Theological Studies 26 (1965): 667-71.

Groves, R. “'His Blood Be upon Us': Matthew 27:15-26.” Review and Expositor 103 (2006): 223-30.

Hilary of Poitiers. “Tractatus super psalmos." Pages 3-354 in S. Hilarii Episcopi Pictaviensis tractatus super psalmos. Corpus scriptorum ecclesiasticorum latinorum 22. Edited by A. Zingerle. Wien: Akademie der Wissenschaften, 1891.

Hilary of Poitiers. "Commentarius in evangelium Matthaei." Pages 10-261 in Sources chrétiennes. Vol. 258. Edited by J. Doignon. Paris: Éditions du Cerf, 1979.

Kany, R. "Die Frau des Pilatus und ihr Name: Ein Kapitel aus der Geschichte neutestamentlicher Wissenschaft." Zeitschrift für die neutestamentliche Wissenschaft und die Kunde der älteren Kirche 86 (1995): 104-110.

Krieger, K.-S. "Pontius Pilatus - ein Judenfeind? Zur Problematik einer Pilatusbibliographie." Biblische Notizen 78 (1995): 63-83.

Kunzig, W. In Search of Asterius: Studies on the Authorship of the Homilies on the Psalms. Forschungen zur Kirchen- und Dogmengeschichte 47. Göttingen: Vandenhoeck \& Ruprecht, 1990.

Luz, U. Matthew 21-28. Hermeneia. Minneapolis: Fortress, 2005.

Nolland, J. "Matthew and Anti-Semitism." Pages 154-69 in Built upon the Rock: Studies in the Gospel of Matthew. Edited by D. M. Gurtner and J. Nolland. Grand Rapids: Eerdmans, 2008.

Origen. "Contra Celsum." Pages 64-476 in Sources chrétiennes. Vol. 132. Edited by M. Borret. Paris: Éditions du Cerf, 1967.

Patrologia Graeca. Edited by J. -P. Migne. 162 vols. Paris, 1857-1886.

Senior, D. P. The Passion Narrative according to Matthew: A Redactional Study. Bibliotheca ephemeridum theologicarum lovaniensium 39. Leuven: Leuven University Press, 1982.

Senior, D. P. The Passion of Jesus in the Gospel of Matthew. The Passion Series 1. Wilmington: Michael Glazier, 1985.

Sider Hamilton, C. “'His Blood Be upon Us': Innocent Blood and the Death of Jesus in Matthew." Catholic Biblical Quarterly 70 (2008): 82-100.

The Nicene and Post-Nicene Fathers, Series 1. Edited by P. Schaff. 1886-1889. 14 vols. Repr., Peabody: Hendrickson, 1994. 
The Nicene and Post-Nicene Fathers, Series 2. Edited by P. Schaff and H. Wace. 1890-1899. 14 vols. Repr., Peabody: Hendrickson, 1994.

Uthemann, K.-H. Die Pseudo-Chrysostomische Predigt In Baptismum et Tentationem (BHG 1936m; $C P G$ 4735). Abhandlungen der Heidelberger Akademie der Wissenschaften. Philosophischhistorische Klasse 3. Heidelberg: Universitätsverlag C. Winter, 1994.

Van Bruggen, J. Matteüs: Het Evangelie voor Israël. Commentaar op het Nieuwe Testament Derde Serie. Kampen: J. H. Kok, 1990.

Van der Bergh, R. H. "The Distinction between Story and Discourse in the Analysis of Biblical Narrative." Journal of Northwest Semitic Languages 34 (2008): 83-98.

Wettlaufer, R. D. “A Second Glance at Matthew 27:24.” New Testament Studies 53 (2007): 344-58. 